\title{
Port Harcourt Port and Inland Waterways in Nigeria, 1913-2010: A Historical Perspective
}

\author{
Grace Malachi Brown, Phd \\ Department Of History And Diplomatic Studies Faculty Of Humanities Rivers State University Of Education \\ P. M. B. 5047, Rumuolumeni Port Harcourt, Rivers State, Nigeria
}

\begin{abstract}
This study traced the historical development of the Port Harcourt Port and Inland Waterways in Nigeria from 1913 to 2010, in view of its economic and socio-political relevance in Nigeria. The study is based on variety of sources - oral evidence, interdisciplinary approach, archival materials, published and unpublished materials. The study observed that the construction work of the Port Harcourt Port began during the British colonial administration in Nigeria, with the construction of the Bonny River between 1913 and 1916 and also witnessed the first shipment through the Port Harcourt Port. By 1923, the cargo section of the Port Harcourt Port was constructed. Between 1923 and 1966, there were remarkable improvements in Port administration. Following the Nigerian civil war between 1967 and 1970, goods were diverted to Lagos Ports, for security reasons. After the Nigerian civil war, the Port Harcourt Port was rehabilitated and the emergence of the National Maritime Authority, helped to improve the Port and inland waterways in Nigeria. The study concluded that the development of the Port Harcourt Port and Inland Waterways, created economic development in Port Harcourt to other parts of Nigeria, being the nerve for the carriage of oil, gas and other petrochemical products to other parts of Nigeria.
\end{abstract}

\section{Introduction}

The City of Port Harcourt is located in the Niger Delta Region of Nigeria and it is the economic base of Nigeria, hence the development of Port and Inland Waterways facilities in the economic growth of Port Harcourt cannot be over-emphasized. The construction of Port Harcourt Port began in 1913 on the Bonny River which was a deliberate attempt by the British colonial administration to develop a port and link it by railway to the coal resources at Udi Hills near Enugu in Nigeria. This was because the export-oriented nature of the resources' exploitation in the country created the need for the development of a seaport, a convenient point of evacuation. The natural habour where the Port Harcourt Port was located approached by the Bonny River and it lies 41 miles from the sea. The approach to its entrance was over the Bonny bar, which vessels could cross only at high water (Ekundare, 1972:257). Although the natural harbour measured about 70 feet deep, it was extensively dredged in order to allow large vessels to enter. However, before the actual construction of the Port, small wharves were built in 1913 to land construction materials for both railway and port. By 1916, a berth for colliers was dredged and its construction was completed in that same year. Thus, in June 1916, the first shipload of coal in the "Sir Hugh" left Port Harcourt Port for Lagos (B. Ogundana, in I.A. Akinjogbin and S. Osoba, 1980: 170). Machinery for the coal mines also went through the Port Harcourt Port from that year.

\section{Development Of Port Harcourt Port And Inland Waterways In Nigeria}

After the completion of the first phase of the port, the construction of the main general cargo wharf began in 1923. This cargo wharf was planned to provide four transit sheds and berthing accommodation for general cargo ships. It was completed in 1927 and provided about 1,920 feet. On its completion, Port Harcourt Port became the second most important Port in Nigeria. As Baba Femi Ogundana noted:

In 1920, the ports of Lagos and Port Harcourt accounted respectively for $45 \mathrm{~F} \%$ of the total ports' traffic of Nigeria (by weight), but their share had increased to $63 \%$ and $17 \%$ in 1950

(B. Ogundana, in I.A. Akinjogbin and S. Osoba, 1980:161).

It was the superior location characteristics of these two ports that made them centers of colonial port development. Thus, in order to make the seaports focal points in international and national transport services, the colonial government incurred an expenditure of 4.8 million pounds to provide port facilities. Although there was little domestic traffic between the Ports, there was substantial increase in its volume during and immediately after the Second World War. 
The years (1914 to 1953) were periods in which ports administration in Nigeria was under the auspices of Marine Department and which did not witness any remarkable port extension. The ports were characterized by narrow passages leading to shallow rivers on which vessels had to sail, and lack of dredging facilities to keep them open as much as possible. For Port Harcourt Port, after completion of the main general wharf in 1927, no further extension work was done. Later plan to embark on its extension was suspended as a result of the Second World War.

However, in 1954, six years before Nigeria's independence, the Nigerian Ports Authority was established as an autonomous public corporation to manage ports and inland waterways. It therefore succeeded the Marine Department, and became responsible for the provision, improvement and maintenance of harbour facilities and services in all ports. Its duties included dredging, hydrographic surveying, buoyage, pilotage, maintenance of lighthouses, towage and salvage. The emergence of the Nigerian Ports Authority ushered a new look in ports' development. For instance, the Ports' Authority introduced new buoyage systems. It also provided river maps, compiled from hydrographic surveys and Gerial photography, together with a network of river gauges for the benefits of shipping (Ekundare, 1973:257).

For the Port Harcourt Port which had increased in its importance because of the establishment of a cement industry and the increased exploration of oil and gas in the areas, the Nigeria Ports Authority embarked on a 4 million pounds project in 1957 to extend the wharf by another 1,600 feet. The wharf extension proceeded satisfactorily after a somewhat uncertain state. On the engineering section, attempt was made in 1958 at linking the existing wharf electrically with the new ring circuit. Construction work also began on the ports' railway track and a new locomotive shed and fueling point were completed and brought into operation. Three M.A.K. diesel locomotives were brought to operate in the area, while the main shipway at the Dockyard was reconstructed. The Port tanker mooring buoys were also re-laid in order to accommodate larger export tankers.

The Nigerian Ports Authority in Port Harcourt also increased the number of pilots in the compulsory pilotage district between Dawes Island and Port Harcourt. In 1958, ships were piloted inwards and 595 ships were piloted outwards. On $25^{\text {th }}$ January 1958, maintenance dredging with the port was commenced, and a total of 52, 935 tons of spoil were removed by G.D. "Mole". Communication facilities were also given attention at the port. In November of the same year, a radio mask was erected at Bonny for use with the channels V.H.F equipment to give satisfaction service to the port (File No. ML/E 070, Nigerian Ports Authority, Third Annual Reports, 1958).

The Port Harcourt wharf which began in 1957 was first opened in October 1960 by Princess Alexendra, a 23 year-old royalty, who represented the Queen at the Nigerian Independence celebrations. Admiring the $4^{1 / 2}$ Million wharf Extension, the Princess declared thus:

From comparative small beginning this port has grown in the space of less than half a century, to be second only to Lagos in importance (File No. FEDLAM 10/14/, N.P.A. New, October 10 1960, P.I).

Generally, the port extension on its completion, had seven general cargo berths which formed a continuous quay of 3,350 feet long with transit sheds having a total surface area of 255,5000 square feet. In addition, there were ancillary stores for cement, carbide and matches. For the storage of exports, there was a produce warehouse of 60,000 square feet and four Arcon sheds. There was provision for the discharge of bulk petroleum at tanker mooring upstream of the port. The main berths were served by rail and road. Mechanical handling equipment including mobile cranes fork lift trucks, trackers and trailers were provided for the Port. Other facilities which were also provided at the Port Harcourt quay included a sea going tug, a dockyard where repairs to river craft were undertaken, fresh water at the main berths and a 200-ton capacity water boat. A fire and ambulance station was situated within the main entrance. In order to provide fresh water to ships, fire hydrants and wharf domestic services, the Ports Authority built 200,000-gallon capacity water tanker (File No. FEDLAB 10/1/4, N.P.A. New, October 10, 1960. P.3).

With these amenities, the volume of export and import transaction of the Port Harcourt Port increased considerably. For instance, the 1959 export tonnage of 278,263 increased to 315,447 tons in 1960. Palm kernels alone showed an increase of approximately 13,000 tons. Cotton lint, tin, columbite and Soya beans also showed improvement. Bulk palm oil shipments increased from 108,491 tons in 1958/59 to 114,600 tons in 1960. There was also notable increase in the quantity of bulk mineral oil shipped. It rose from 290, 140 tons in 1958/59 to 653,521 tons in 1960.The same increase occurred on imports. Imports handled over the Port Harcourt quay reached a new high level of 414,824 tons, this being an increase of 52.250 tons or $14.4 \%$ over the 1959 record. Cement was the main import, which compared with 1959 record, increased from 115, 791 to 136, 210 tins, and 
accounted for $32.8 \%$ of total imports. Also, there was an increase in the import of staple commodities such as flour, salt and stock-fish. The import of second-hand clothing also showed substantial increase (N.P.A $5^{\text {th }}$ Annual Reports, 1960).

In 1965, the Nigerian Ports Authority, Port Harcourt, registered four premises under the Factories Act 1955 as separate undertakings. The premises were the Dockyard, Port Engineer's Works Yard, Engineering Department, and Electrical Department. The Dockyard was responsible for woodworking and Block making. The Engineering Department maintained and repaired wharf plants and vehicles while the Electrical Department was in charge of electrical repairs and maintenance. However, in 1966, following the recommendation of H.A.N. Fige Davies, the Senior Inspector, Factories, Eastern Nigeria, the premises were merged into two main units, namely, Ship Building and Wood Section as one, while the Electrical repairs, maintenance, repairing of wharf plants and vehicles formed the other unit (File No. ML/E. 0177, Nigeria Ports Authority, Engineering Department, Port Harcourt Quays, 1966).

Apart from the services rendered by the Nigerian Ports Authority in the promotion of export-import transactions, there were other government-owned and private firms whose activities boosted coastal services in Port Harcourt. Among these coastal related firms were Elder Dempster Agencies Limited, Government Coastal Agency, African and Overseas Agencies Limited, Panalpina World Transport Nigeria Limited, Umarco Limited, Witt and Busch Shipyard, and Intercotra Agency Limited. The Elder Dempster Agencies Limited which had been a Pioneer Colonial Shipping Agency in Nigeria, extended its coastal services to Port Harcourt Port in 1952 and from then the Port depended on it for the provision of mailboats.

The Government Coastal Agency was established in Lagos in 1956 by the Federal Government to provide coastal services to Nigerian ports. On the $1^{\text {st }}$ of January, 1957, the Port Harcourt branch was established to take over the Embrayo organization which had hitherto been operated by the Eastern Region Ministry of Transport. Before the opening of the branch, the Coastal Agent and an Acting Senior Accountant visited the Port to assess the task, and following this visit, the branch was opened. Its office was first in a corner of the District office but was later moved into rented premises on Harbour Road, Port Harcourt. From the inception, qualified officers were transferred to build up an efficient branch office. A lorry, typewriter and stationery were also handed over by the Eastern Region Government to the branch (Government Coastal Agency, Second Annual Report, 1957, P. 3). The Government Coastal Agency transacted business for government and private departments such as the public works departments of various Regions, the Posts and Telegraphs Department, and the Marketing and Exports Department. The total quantity of imports transacted by the Port Harcourt branch of the Government Coastal Agency on behalf of its clients during this period, January to March, 1957, is demonstrated in the table below:

TABLE 1

TOTAL TRANSACTION OF PORT HARCOURT COASTAL AGENCY (JANUARY-MARCH 1957) PACKAGES C.I.F. VALUE OF CUSTOMS DUTY PAID

\begin{tabular}{|l|l|l|l|}
\hline FEDERAL & 402 & 15,814 & 3,873 \\
\hline NORTHERN & 961 & 4,457 & 4,901 \\
\hline EASTERN & 5,637 & 60,609 & 6,641 \\
\hline TOTAL & $\mathbf{7 , 0 0 0}$ & $\mathbf{8 0 , 0 0 0}$ & $\mathbf{1 5 , 4 1 5}$ \\
\hline
\end{tabular}

Sources: Government Coastal Agency Second Annual Report 1957, National Archive, Port Harcourt.

Following the increase in the volume of its transactions, the Port Harcourt branch office of the Agency was moved to Industry Road, Port Harcourt in 1961, close to the Port Harcourt Port/wharf and the shipping lines. From this modern office, the Agency transacted its business daily. However, the 1967 Nigerian civil war disturbed the Agency's services in Port Harcourt for some months as there was exodus of staff from the branch. Arrangements were made for staff of Eastern Nigerian origin to be deployed to Port Harcourt. 
The construction by Panalpina World Transport Nigerian Limited and the African and Overseas Agencies Limited, in the promotion of coastal services in Port Harcourt were also very significant. The two agencies were located on the Industry Road of Port Harcourt and they featured most in clearing, forwarding and shipping business on $1^{\text {st }}$ August, 1965. The African and Overseas Agencies Limited changed its name to Transport Limited and moved its office to No. 8 Azikiwe Road, Port Harcourt (File No. PHI/71404, Panalpina World Transport, 1965; PHI/715020, Transcap Limited, 1965).

Mention must also be made of the Witt and Busch Shipyard Limited. This company, though did not engage in forwarding and clearing business, but made great impact on inland coastal services in Port Harcourt. The company was a subsidiary of the Witt and Busch Limited, a company founded in Nigeria in 1876. The Witt and Busch Shipyard Limited was incorporated on $3^{\text {rd }}$ July, 1964 with a directorate office at No.2 Aba Road but its permanent office was later built along the Bonny River, where it acquired a $4^{1 / 2}$ acre of land.

The Witt and Busch Shipyard Limited engaged in the repair and servicing of ships and building of new steel boats, dingies and barges. The shipyard had five sections which include welding, carpentry, machine shop, mechanical, repairs and building. Their regular customers were B.O.P. Nigeria Limited, Drilexco, Inland Waterways, Niger Delta Development Board, Customs, Shell-B.P, International Drilling Company, Marine Services, Police, Ministry of Health and several notable companies and some river fishermen (File No. T. 4584, Witt and Busch Shipyard Limited, Status Report, 1966, P.I). The Company built and repaired crafts and barges for these firms. The company imported materials such as steel metals, electrical accessories, electrodes and spare parts from the United Kingdom. The most important of the ships built by the Witt and Busch Shipyard Company were the House Boat and the Cinema Boat. The House Boat was built for a drilling company while the Cinema Boat was built for the Ministry of Information, Eastern Group.

It should be noted at this juncture that the situations described above were the activities of port and inland waterways in Port Harcourt up to 1966, and within this period, the Port Harcourt Port handled about one fourth of the exports and imports through the Nigerian harbors. The period (1967 to 1970) was beset by civil war, and during this period the port was closed down. The immediate post war years were characterized by the reconstruction of the damaged port facilities. This reconstruction activity of the Port Harcourt Port, transformed its operations and facilities into a full-scale port operation. Thus, between 1971 and 1973, not less than 16 percent of all cargo traffic was handled at Port Harcourt (Ogionwo, 1979:204).

Government investment in port facilities during the period was concentrated in Port Harcourt and Lagos ports. For instance, within the third national development plan, six berths were added to the port complex at Port Harcourt at a cost of N40 Million. In order to ease traffic congestion at Port Harcourt Port, a new lighter terminal was constructed. By the end of 1975, the port had three major port facilities. Additionally, two installations that serve the petroleum industry were constructed. One was the oil jetty at Okrika, which was an on-loading base for oil and gas and petroleum products from the nearby refinery. The other was the Bonny terminal, a crude oil and gas on-loading facilities connected by pipelines to the oil and gas fields. It was situated at Bonny at the estuary of the Bonny River (File No. 57, contracts, 1975).

In an effort to reconstruct and rehabilitate the port facilities that were damaged during the Nigerian civil war years, the federal government invested large sums of money on port development project under the third national development plan (1975-1982). Within this period, about four new ports were built - one at a cost of N193 Million Naira in 1979; the third Apapa Wharf was built also in 1979 at the cost of Eighty Million (N80, 000, 000); and the Onne terminal Port Phases one and two built to decongest the old Port Harcourt township Wharf at the cost of Twenty One Million Naira (N21, 000, 000) and commissioned in April 1979 and November 1982 respectively (Anyanwu 1997: 368).

\section{THE ROLE OF THE NIGERIA'S NATIONAL MARITIME AUTHORITY}

In the fourth national development plan (1981-1985) a total of about N961.52 Million representing about $8.99 \%$ of the total N10, 706.6 Million planned for the development of the transport sector was allocated to sea port development. The period (1987 to 1993) witnessed a tremendous economic growth in port activities. This was as a result of the promulgation of decree 10 of $10^{\text {th }}$ April 1987 known as the "National Shipping Policy" and thereafter the "National Maritime Authority". This body was organized to regulate shipping activities in Nigerian Port. This was a protectionist policy designed to build a national fleet for economic and security purpose (Zaria 1999:25). 
Some of the aims and objectives of the national maritime authority were improvement of Nigerian balance of payments; promoting the acquisition of shipping technology, and creating and diversifying employment opportunities in the shipping industry through the stimulation and protection of indigenous shipping companies. Another objective of this body was to ensure the training of Nigerians in maritime transport technology and seafaring to archive a systematic control of the mechanism of sea transport (National Maritime Act Decree 10 1987:6).

Other functions of the national maritime authority included to co-ordinate the implementation of the national policy on shipping, to ensure that Nigerian national carrier exercises fully Nigerians the carrying rights of at least 4-percentage of the fright in revenue and volume of the total to and from Nigeria, to grant national carrier status to indigenous shipping lines; and to monitor the archive of vessels of the companies granted national carrier effective of Nigerian port and also guarantee ports its safely of which Port Harcourt Port is inclusive.

According to the Nigerian ports authority annual reports of 1995, all the operational private jetties in Port Harcourt Port complex were effectively monitored by a combined team of the navy and National Maritime Authority (NMA). Consequently, the complex activities of illegal bunkerers were grossly minimized. Ships of various Nationalities berthed at the Port Harcourt seaport. Data collected over a ten-year period, 1985 to 1994, showed that an average of 196 ships berthed annually in Port Harcourt seaports. The highest number of ships that entered and cleared at the port, during this ten years period, included on the average annually; 27 Nigerian ships; Cypriot 22; Panalpina 20; British 17; Greek 11; Dutch 10; Bahamian 10; Liberian 11; and Norwegian 10. In terms of Net Registered Tones (NRT), the port recorded an annual average of 927, 097 tones over the tenyears period, 1985 to 1994 (Nigerian Port Plc Annual Report 1993:94). The cargo report of Port Harcourt seaport 1990 and 1995 showed an average of 1, 130, 900 metric tones of cargo report. The table below illustrates the cargo report of Port Harcourt Port 1990 - 1995)

TABLE 11

CARGO THOUGHT: PORT HARCOURT SEAPORT (1990-1995). Period Discharge '000 loaded '000 Total' 000

Tonnes $\begin{aligned} & \text { Tonnes } \\
& \text { PH Ports PH All }\end{aligned}$
\begin{tabular}{|l|l|l|l|l|l|}
\hline 1990 & 776 & 9,338 & 81 & 6,829 & 857 \\
\hline 1991 & 1,144 & 7,737 & 113 & 78,594 & 1,257 \\
\hline 1992 & 1,278 & 10,999 & 121 & 68,954 & 1,399 \\
\hline 1993 & 1,405 & 10,405 & 65 & 84,232 & 1,470 \\
\hline 1994 & 776 & 7,968 & 51 & 86,305 & 827 \\
\hline 1995 & 916 & 9,020 & 59 & 89,121 & 975 \\
\hline AVERAGE & $1,049.2$ & 9,245 & 81.2 & 69.021 & $1,130.8$ \\
\hline
\end{tabular}

Sources: Annual Reports 1992 and 1993 - Nigerian Ports Plc. Eastern Zone.

Though Port Harcourt Port was flourishing economically within the period under review, it also suffered some operational setbacks. The Nigeria Ports Bulletin (1995) stated some of the problems of the ports as:

Conflicting roles and activities of multi-various security agents at the ports and this has been associated with the porous nature of the ports in the port complex. Arbitrary, uncontrolled and uncoordinated charges, nuisance of "wharf rats" who pilfer and port related fraud (Oyegun 1999:226). 
Between 1999 and 2010, low productivity rate reported by some workers due to the importation of certain goods prohibited by the Nigerian government, lack of spare parts to maintain the ships and general lack of maintenance culture. In an interview with Mohammed Isa, he has this to say about the activities of the Port Harcourt Port since 2000:

Because of too much checking by customs and some government agents the ships are no longer coming as before...(16/11/2005).

As stated earlier, the period from late 1966 to 1970 were characterized by the Nigerian civil war. Though Inland Coastal services was not highly developed in Port Harcourt before the war, it was also seriously affected by the war. But after the Civil War, water transport within the creeks and its environs was also developed. Thus, during the 1970-74 plan period, significant success was achieved in respect of water transport. For example, six passenger ferry boats capable of carrying 200 passengers each were bought by the Rivers State Transport Corporation and put into service. The Transport Corporation had its ferry terminal on Amadi Creek. Regular ferry services to Bonny are combined to Buguma and Degema riverine communities in Rivers State, Nigeria; and to Nembe and Brass reverine communities in Bayelsa State, Nigeria. With the development of these ferry services, by 1975, several persons utilized these ferry services.

Between 1975 and 1980 major water sides of jetties had been developed. These were Abonnema Wharf Jetty, Okrika, Marine Base, Abuloma Jetty, Creek Road or Bonny waterside and Rumulomeni waterside (Iwofe). All these jetties provided transport services to the riverine communities of Rivers State. From 1980 modern modes of sea transport such as the speed boats (of both outbroad and inboard engines) made sea transport easily assessable, safer and faster to the riverine communities. For instance, between 1970 and 1980, people usually spent 2-3 days on water by the use of local boats or canoes before getting to places like Nembe, Brass or Bille riverine communities in the Niger Delta Regions of Nigeria. The Rivers State Transport Corporation, private companies and individuals provided modern water transport services.

Beginning from 1995 and 2010, the inland waterways started to decline in some areas of Port Harcourt. This was due to the construction of roads linking Port Harcourt to some riverine communities such as Abonnema, Buguma, Degema, Abuloma, Ogbakiri, etc. In order to enhance the effectiveness of water transport, the Rivers State Government through its Restoration Programme, purchased eight passenger boats for riverine commuters. Also, the Nigerian government has modified the laws associated with the ports and inland waterways. For example, the Nigerian Ports Authority Act, 1999; Carbotage Act, 2004 and the National Maritime Authority Act, 2004.

\section{IMPORTANCE OF PORTS AND INLAND WATERWAYS IN NIGERIA}

The importance of ports and inland waterways cannot be over-emphasized. It does not only serve as a shelter for ships and goods but also perform other socio-economic function in any society. The ports generate foreign and local revenue and investment to any government. Goods are usually imported and exported through ports and the investors pay duties and taxes to the port administrators. It creates room for employment in the society. The port serves as a tourist centre for people and nations of different backgrounds - be it economic, social, political and cultural, as they come together to use these services. Businessmen, students and all sorts of persons visit the ports for excursion, leisure and business activities. Due to the hazardous nature of some goods like oil, gas, petroleum products and industrial equipments, etc, it is more convenient to transport them through the ports and inland waterways than by roads. Ports activities help to promote urbanization and industrialization of any city and to ease traffic congestions. In spite of the importance of ports and inland waterways, it has some disadvantages such as the use of it for arms deals, drug trafficking and other forms of social vices.

\section{Conclusion}

In this study, we have observed that the establishment of Port Harcourt Port attracted industries, firms and above all, created employment for its teaming population. The existence of inland water transport within and outside Port Harcourt enhanced the economic growth of the city as the inland waterways created an important linkage for commercial and business transactions. Businessmen utilize the opportunity of the inland waterways to convey their goods to nearby states or areas of the country so as to enable them transport them to their respective business firms or organizations. 


\section{References}

[1]. Akinjiogbin, Isaac and Osoba Segun, Topics on Nigerian Economic and Social History, Ile Ife: University of Ife Press, 1980

[2]. Anyanwu, John and Aloa Oyefusi, The Structure of Nigerian Economy 1960-1997, Onitsha: Joanee Educational Publishers, 1997.

[3]. Ekundare, Olufemi, An Economic History of Nigeria 1860-1960, London: Methuen and Company, 1973.

[4]. Ekundare, Olufemi, An Economic History of Nigeria 1860-1960, London: Methuen and Company, 1973.

[5]. Knowless, Lucius, Economic Development of the British Overseas Empire, London: Heinemann, 1924.

[6]. Kure, Abraham, National Maritime Authority Planning Research and Statistics Department, "Report of the study on the establishment of Maritime Sabotage in Nigeria", 2001.

[7]. Maduka, Ozilli, Port Safety and Environmental Management, Lagos: Concepts Publciations, 2004

[8]. National Archive, Annual Reports on the Government Coastal Agency, 1957, 1958, 1961, 1971. File No. Port Harcourt, 1972.

[9]. National Archive, Contracts, File No. Mjsc. 57, Port Harcourt, 1975.

[10]. National Archive, Costain (West African) Limited, File No. E. 0170, FEDLAB 3/1/7. Port Harcourt, 1967.

[11]. National Archive, Nigerian Ports Authority. Engineering Department, Port Harcourt Quays File No. ML/E. 0177.Port Harcourt 1960 .

[12]. National Archive, Inspection Report on Nigerian Railway Corporation; Carriage and Wagon File No. E.0049, FEDLAB 3/1/5, Port Harcourt, 1957.

[13]. National Archive, N.P.A. News October 10, 1960 File No. FEDLAB 10/1/4, 1947. Port Harcourt 1960:3

[14]. National Archive, Panalpina World Transport Nigeria Limited File No. Ph/31002. Port Harcourt, 2000.

[15]. National Archive, Status Report on Witt and Busch Shipyard Limited File No. T4584. Port Harcourt 1964

[16]. National Archive, Status Report on Witt and Busch Shipyard Limited File No. T4584. P.I Port Harcourt 1966

[17]. National Archive, Nigerian Ports Authority, Nigeria Authority File No. ML/E. 0177, Engineering Department, Port Harcourt Quays Port Harcourt. National Archive Enugu. 1966

[18]. Ogali, Titus, "Witt and Busch Shipyard Project No. 1", Eastern Nigeria Guadian 23 June 1966:8.

[19]. Ogionwo, Williams, The City of Port Harcourt: A symposium on its Growth and Development, Ibadan: Heinemann, 1979.

[20]. Zaria, Ibraham, "Marketing Mix: Appraisal of its Application in the Maritime Industry A case study of National Maritime Authority”, Unpublished MA thesis, Faculty of Social Sciences, Rivers State University of Science and Technology, 1999. 